\title{
PERENCANAAN SALURAN DISTRIBUSI
}

\author{
Hanan Fakhira Sa’diyyah \\ Naura Aulia Hafidzah \\ Muhammad Zaidan Mubarak \\ Mumuh Mulyana \\ Sofie Kurnia Asih
}

Selamat berjumpa lagi. Apa kabar para mahasiswa? Semoga Tetap Semangat ya...

Di inisiasi VII ini akan membahas materi Perencanaan Saluran Distribusi. seperti biasa, silahkan pelajari modul 8 dari BMP Perencanaan Pemasaran (EKMA 4569).

Jangan lupa untuk mengerjakan tes formatif modul 8 untuk mengevaluasi kemampuan pemahaman Anda tentang materi tersebut.
Kompetensi Umum
: Mahasiswa diharapkan mampu memahami dan menjelaskan konsep dasar dan perancangan perencanaan pemasaran serta aplikasinya dalam bauran pemasaran
Kompetensi Khusus
: Mampu menjelaskan dan Merumuskan Perencanaan Saluran Distribusi
Menjelaskan Pentingnya Perencanaan Saluran Distribusi
Menjelaskan Proses Desain Saluran Distribusi
Menjelaskan Bauran Saluran Distribusi
Menjelaskan Manajemen Distribusi Terintegrasi

\section{Sumber Belajar}

1. Utama

Modul 8 EKMA4569

Perencanaan Pemasaran. Daniel Tumpal. Universitas Terbuka. 2016

2. Tambahan:

- Marketing Management : A Strategic Decision-Making Approach. John W. Mullins and Orville C. Walker, Jr. $7^{\text {th }}$ edition. McGraw-Hill International Edition. 2010

\section{Rangkuman Materi Kuliah}

Perusahaan perlu membangun suatu manajemen saluran yang efektif dengan cara mempertimbangkan dan menganalisis faktor-faktor permintaan dan merancang saluran distribusi yang terintegrasi. Desain saluran yang responsif merupakan karakteristik saluran distribusi yang optimal untuk mencapai segmen konsumen akhir yang dipilih. Faktor lingkungan serta 
keterbatasan manajerial perlu dimasukkan dalam upaya mengidentifikasi dan menutup kesenjangan saluran sampai seminimal mungkin. Juga tetap memantau isu-isu yang ada berkaitan dengan pelaksanaan desain saluran yang optimal yang efektif.

Fungsi Saluran Pemasaran

1. Sebagai Penyedia Informasi

2. Mempromosikan produk

3. Melakukan negosiasi

4. Melakukan pemesanan

5. Menfasilitasi pembiayaan

6. Mengambil risiko

7. Kepemilikan fisik

8. Memfasilitasi pembayaran

9. Hak milik

Kotler (2001) menyatakan empat hal utama dalam mendesain saluran pemasaran, yaitu :

a. Menganalisis tingkat hasil pelayanan yang diinginkan pelanggan

b. Menetapkan tujuan dan batasan saluran pemasaran

c. Mengidentifikasi alternatif saluran utama

d. Mengevaluasi alternatif saluran pemasaran utama

Dalam memilih alternatif saluran, ada tiga elemen yang perlu diperhatikan yaitu jenis perantara, jumlah perantara dan persyaratan \& tanggungjawab anggota saluran.

Sejumlah komponen atau atau variabel yang merupakan bagian-bagian dari bauran distribusi adalah sebagai berikut :
a. Fasilitas
b. Persediaan
c. Transportasi
d. Komunikasi
e. Penyatuan Barang

\section{Alternatif Saluran Distribusi}

Saluran pemasaran dapat dibedakan menurut jumlah tingkatannya. Dalam menetapkan alternatif saluran pemasaran yang akan digunakan, perusahaan juga dapat mempertimbangkan jenis produknya. Untuk produk industrial, biasanya perusahaan menggunakan saluran langsung atau pendek.

\section{Saluran Untuk Produk Konsumen}

Saluran pemasaran untuk produk konsumen terdiri dari:

- Saluran distribusi langsung (nol tingkat), yaitu saluran pemasaran dimana seorang produsen langsung menjual ke pemakai akhir. Cara yang dilakukan antara lain melalui penjualan dari pintu ke pintu, arisan ibu-ibu, pemesanan lewat telepon, email atau online, penjualan lewat teve, dan melalui toko-toko yang dimiliki produsen sendiri.

- Saluran distribusit satu tingkat, yaitu hanya ada satu perantara pemasaran di antara produsen dan konsumen. Ada dua alternatif dalam saluran satu tingkat, yaitu:

1) produsen $\rightarrow$ pengecer $\rightarrow$ konsumen; 
2) produsen $\rightarrow$ pedagang besar $\rightarrow$ konsumen

- Saluran distribusi dua tingkat, yaitu ada dua perantara pemasaran di antara produsen dan konsumen. Jadi produsen menjual produknya ke pedagang besar, yang pada gilirannya menjuanya ke berbagai pengecer, sebelum sampai ke kosnumen akhir. Ilustrasinya yaitu: produsen $\rightarrow$ pedagang besar $\rightarrow$ pengecer $\rightarrow$ konsumen .

\section{Saluran Untuk Produk Industrial}

Perusahaan barang industri dapat menggunakan tenaga penjualnnya untuk menjual langsung ke pelanggan industri. Perusahaan barang industri/ para pabrikan membeli bahan mentah dalam kuantitas besar, bahan baku yang diolah, dan perlengkapan secara langsung dari pabrikan lainnya.

Beberapa perusahaan menjual produk-produk dengan kategori standar nilai sedang atau rendah menggunakan distributor industri sebelum ke pelanggan industri. Disributor industri ini seperti layaknya swalayan bagi sejumlah organisasi. Distributor industri merupakan grosir dan anggota saluran yang membeli dan mengambilalih hak sejumlah produk dengan cara menyimpan persediaan produk.

Pada kasus tertentu, para pabrikan yang tidak mampu mempekerjakan tenaga penjualnya, mengandalkan perwakilan pabrikan atau agen penjualan utuk menjual produk industrinya apakah langsung ke pelanggan industri, atau ke distributor industri.

\section{Integrasi Multi Saluran}

- Penyedia Saluran Tunggal

- Pemindah Saluran

- Strategi Berdasar Aktivitas

- Strategi Multi Terintegrasi

- Strategi Segmentasi Berdasarkan Kebutuhan

- Strategi Nilai Customer Graduated

\section{Referensi :}

[1] Tumpal, Daniel, 2016. Perencanaan Pemasaran. Universitas Terbuka.

[2] McDonald, Malcolm and Wilson, Hugh. 2011. Marketing Plans: How To Prepare Them, How To Use Them. $7^{\text {th }}$ edition. Wiley.

[3] Mullins, John W. and Walker, Jr. Orville C., 2010. Marketing Management : A Strategic Decision-Making Approach. $7^{\text {th }}$ edition. McGraw-Hill International Edition.

[4] O'Guinn, Thomas C.; Allen, Chris T. and Semenik, Richard J., 2009. Advertising \& Integrated Brand Promotion. $5^{\text {th }}$ Edition. South-Western Cengage Learning.

[5] Crawford, Merle and Benedetto, Anthony Di 2011. New Products Management. $10^{\text {th }}$ Edition. McGraw-Hill International Edition. 2011.

[6] Mulyana, Mumuh. 2019. "STRATEGI PROMOSI DAN KOMUNIKASI." INA-Rxiv. June 12. doi:10.31227/osf.io/v7dfr.

[7] Mulyana, Mumuh. 2019. "MENGANALISIS PERILAKU KONSUMEN." INA-Rxiv. June 12. doi:10.31227/osf.io/2wj34.

[8] Mulyana, M., 2012. Consumer Behaviour: Sukses Dengan Memahami Konsumen.

[9] Mulyana, M. and Sulistiono, S., 2012. Kewirausahaan: The Long Life Way of Business. 
[10] Pauziah, P. and Mulyana, M., 2018. Formulation of The Green Marketing Development Strategy for the Body Shop Botani Square Bogor. In THE INTERNATIONAL CONFERENCE ON ACCOUNTING AND MANAGEMENT SCIENCE (p. 171).

[11] Hidayat, L., Mulyana, M. and Effendy, M., 2018. Membangun Kepuasan Mahasiswa Pengguna Laboratorium Komputer. JAS-PT Jurnal Analisis Sistem Pendidikan Tinggi, 1(2), pp.93-101.

[12] Mulyana, M., PERSEPSI DAN PERILAKU KONSUMEN TERHADAP ONLINE SHOPPING. 